\title{
The Individual and the Social: \\ Limits of Nomological Synthesis and Powers of Social Analytics
}

\author{
Olga F. Neskriabina* \\ Siberian Federal University \\ 79 Svobodny, Krasnoyarsk, 660041, Russia
}

Received 20.12.2016, received in revised form 13.03.2017, accepted 20.03.2017

The article discusses some problematic relations between the individual and the social levels of existence and cognition of society. It states diversity and lack of integration of methodological approaches to the analysis of a systemic organization of society.

The article also raises the question of the ontological status of the "level" category. The author comes to the conclusion that the "level" belongs to two languages of the object description: the subject language and the meta-language, the fact being not always taken into account when it comes to creation of generalizing concepts that reflect the specificity of social determinism, the specificity of the "part-whole" relationship in the system, including consciousness, goal-setting, and creativity.

The author states that the methodological pluralism is a reflection of an antinomic nature of the "individual-social" ("I-S") pair, the nomological synthesis is limited to this antinomy, and the analysis of these bounds (limits) has a heuristic significance. It implies clarification of the content of the psychological analysis to understand social realities.

Psychological explanation works for the events in loci that are sensitive to individual characteristics of the subjects of social action.

Social determinism is characterized by a different depth of interpenetration of the individual and the social; availability of dynamic and probabilistic regularities, a different degree of similarity of the elements and the system, the individual and the social.

The consequence of these features is that it is not always correct to explain social realities by deep historical reasons, since the individuality in the society is manifested, in particular, in a certain historic period which will be included in actual social existence. The explanation of social realities by the past condition of the society is limited to the points of choice and / or creativity.

Keywords: system, level synthesis, methodology, social analytics, social determinism, individuality.

DOI: 10.17516/1997-1370-0065.

Research area: philosophy.

\section{Problem statement}

In the context of ongoing divergence of sciences, multiplication of methods and, respectively, languages that describe social realities there arises the need for the nomological synthesis. It implies integration of concepts of high level of generality. However, the presence of demand does not mean the availability and, moreover, guarantee of its satisfaction.

(C) Siberian Federal University. All rights reserved

* Corresponding author E-mail address: nescr@mail.ru 
The problematic character of the nomological synthesis is conceptualized in the "individual-social" opposition. From the position of methodological optimism, this synthesis is principally achieved through intelligent work that involves the language of systemic analysis, synergetics, etc. It was dialectical logic that was applied to solve the philosophical conflicts of this kind.

There have been attempts to use the complementarity principle for this purpose. On the one hand, this principle is applied for the analysis of a physical reality. On the other hand, it does not eliminate the antinomy in microand macrocosm description. There was no such meaningful scanning for the application of this principle with regards to I-S, but the antinomy was preserved.

The point of methodological optimism is that the synthesis problem solution is considered possible regardless of the success of specific scientific knowledge. Yet, if the solution does not depend on broadening and deepening of the empirical base, why is the nomological synthesis not implemented so far?

According to a different approach, formulation and solution of integration problems are associated with the discoveries in the field of anthropology. Yet, its perspectives are not clear: what knowledge does the synthesis lack, in which area is breakthrough possible? A complex of psychological and sociological sciences in their traditional theoretical and methodological boundaries hardly contains such potencies. At present, high expectations are connected with the development of neurobiology (Chernigovskaia, 2013). However, if we understand how neuronets give rise to subjectivity, can we expect that systemic relations of the individual and the social levels of activity in spatial and temporal (historical) aspects of life will be understood? The issue is still considered open.
The variant of methodological anarchism, matching with a postmodern idea of the equivalency of texts, lack of hierarchy, etc. is possible. According to S.A. Kravchenko, the "movement towardsadynamicnetworkinteraction of theoretical-methodological approaches, in which it is almost impossible to distinguish the dominant theory..." have surfaced in sociology (Kravchenko, 2012, p. 19). The last part of the phrase about the impossibility to distinguish the dominant theory needs no explanations. As for the network interaction, there arises an issue of its properties and effectiveness. In our view, "network interaction" is far from being a very good metaphor. It evokes an image of a flat space with no depth.

There has been an active development of discourse analysis methods applied to the analysis of social practices in the course of the last decades (Ticher, 2009; Jorgensen, Phillips, 2008; Leontovich, 2011). The multiplicity of approaches and methods is felt by some authors as a kind of some intellectual challenge, a need to adhere to the key principle of a comprehensive analysis. A comprehensive analysis "requires that one weighs the approaches up against each other with respect to philosophical premises, theoretical claims, methodology and method, identifying what kind of contingent knowledge each approach can supply..." (Jorgensen, Phillips, 2008, p. 252).

Overall, the situation with the methodology of social analytics is quite confusing, which makes it necessary to continue research in this area.

This article is an attempt to define some essential terms of an integrative process and its fundamental limitations.

In the methodological aspect, it will clarify the conditions of identity and differences in the psychological and the sociological levels of social analytics. That gives an opportunity to deepen 
the understanding of individual meanings of social activity, on the one hand, and social effects of individual actions, on the other hand.

\section{The logical and methodological analysis of I-S}

More than a century-long experience of discussion of the I-S relation suggests that the opposition is an antinomic pair (Zdravomyslov, 2012). Therefore, the productive discourse, in our view, should be not so much about the conditions of synthesis, but about its limits and heuristic possibilities.

It is worth while considering some features of the I-S opposition. In our opinion, one of the most problematic options of the approach to the analysis of this opposition is its representation by the "level" concept. The complexity of this concept lies in the uncertainty of the ontological status of its object that leads to the possibility of the concept hypostasis.

Ontologization of the "level" is based on the integrity argument. It is argued that the system object has inherent properties that other elements lack. However, this obvious fact can be given a different interpretation: the emergence of new properties eliminates the so-called level of elements depriving it of its independent existence. Here it is important to keep in mind that similar description is applicable to simple systems only.

Advocates of holistic conceptions of irreducibility of the properties of the whole to the properties of its parts give an old example about the properties of water and the properties of its elements (Kravchenko, 2013, p. 208). But they do not notice that this kind of analogy is equivalent to the reduction of complexity, since the principles of the arrangement of systems of different degree of organization are considered identical. In theoretical terms the issue of nature of system qualities can be solved as the determination of the mechanism of the assembly processes (Moiseev, 1990, p. 54).

The properties of oxygen and hydrogen in water molecules are "tied", they do not show up as such. We can say that there is no "element level" in this system. Can the same be said about the public system? Apparently, another peculiarity manifests itself here, the peculiarity being the autonomy of the elements, diversity of the process of adjusting the elements' properties to the structure, tangle of "horizontal" and "vertical" relations into contours, etc.

The presence of levels as ontological entities can be attributed to the system in which both the system properties and the properties of its elements are revealed. And all these arguments about the meaning of the "level" concept are mainly reduced to the problem of system qualities generation, causality loci identification. According to Iu.V. Sachkov, "the processes at each level have a relative independence, the causality issues are originally solved at each of them" (Sachkov, 2006, p. 34).

K. Popper argues that "social phenomena, including collectives, should be analyzed in terms that refer to individuals, their actions and relations between them" (Popper, 2004, p. 565). According to him, the social system is not an empirical object but a theoretical construct (Ibid., p. 564). Therefore, the "level" is an idealization but not a real object. This decision, in our opinion, does not reflect all possible states of social existence. In a sense, the society acts as an empirical object. Individual activity is limited to the institutional framework represented by legal and cultural norms, material resources movement, etc. Social objectness and role regulatory relations between the subjects, involved in this situation, are revealed to each individual as the objective conditions of his / her activity.

On the other hand, if only the irreducibility of social patterns to the level of the individual 
life is registered, it implies the recognition of an individual's complete dependence on the society. In this conceptual scheme the personality is forced to take the place of the derived value (Neskriabina, 2001, p. 37).

The principles of systemogenesis are, probably, different in the objects of various complexities. When the matter concerns a systemic organization of objects, including the level of consciousness, i.e., when the matter concerns a man and the society, there appears a significantly new circumstance. Such is a person's ability to involve the results of his / her analytical and subjective-evaluative activity in the process of activity determination.

It should be recognized that the "level" is a concept with an underspecified content. This semantic ambiguity is not always explicit, which leads to confusion and unnecessary debates. The "level" is a concept belonging to two "worlds" the language of the object and the meta-language. Society as a system has the levels when considered in relation to the institutions, hierarchy of statuses, and the subjects of decision-making, accordingly. As a term in the system of meta-language the "level" implies the depth of penetration into the object's structure, the transition from empirical to theoretical cognition (Bazhenov, 2006, p. 68).

Thus, this concept implicitly contains duality. Therefore, to talk about the individual and the social as levels is to register this duality without clarifying its nature. In fact, the term "level" is the expression of "the individual and the social' antinomy and identification of the boundaries of the nomological synthesis.

It seems no logical-methodological explication of the "I-S" pair can lay claim to completeness and finality of conclusions. In our opinion, it is K. Popper's productive idea that philosophical conceptions should be discussed in their projections on the middle logical level. "A theory is comprehensible and reasonable only in its relation to a given problem situation, and it can be rationally discussed only by discussing this relation" (Popper, 2004, p. 332).

The problem of correlation between the individual and the social has many urgent projections. In particular, the following options are meaningful and verifiable: the meaning of historical argument, the motivation of an individual action and its social meaning, continuity (tradition) and variability in culture, the nature of ethnic identity and authoritarianism complex, attribution of responsibility, modules of power relations, etc.

\section{The psychological approach to the analysis of the social medium}

Understanding of influence of the characteristics of the psychosphere on the course of events in the social sphere is often associated with the definition of common and essential properties of the human psyche which are important from the point of view of socio-historical dynamics. We argue that it is necessary to analyze the unique properties of the psychosphere in the loci sensitive to the individual characteristics of the subjects of activity.

Social factors, affecting an individual's consciousness and behavior, differ in depth of penetration into the personality structure. It has an adequate conceptual design in such psychological concepts as the autonomy of motivational and cognitive substructures, subjectivity, individualization, creativity.

Concordant and discordant processes and properties coexist in the psyche. It is often impossible to predict which one will be stronger and to define a leading tendency. Creativity manifests itself in the unpredictability of individual and social responses. All these features of the human psyche in themselves are well known. Yet, they are insufficiently explicit in the theory of socio-psycho-interactions. 
Probabilistic and dynamic types of determination are successfully put into effect in socialmedium, which implies an ambiguous nature of the relation between past and future states. It is important to emphasize that probabilistic and dynamic types of determination are not assigned to any of the levels, either individual or social.

The property of equifinality or a person's ability to come to the same conclusion and choose one modus of behavior when having different assumptions and reasons is of a particular interest for understanding psycho-social relations. An ability to divergent thinking and choice is a property which is opposite of equifinality. Potentially any of the properties of psyche can play an independent role in a social action determination. Which of them will emerge and assert itself in a given place and time is a question the answer to which requires the analysis of a particular situation.

If the human psyche is governed by the determinism laws and functions as a single entity, its cause-effect relations form continuous sequences. If the determinism and integrity form the two extremes in the continuum of possibilities, the individualizing method is necessary, the method limiting the depth of the convergence in the cause-effect chain and the generalization level. Modern cognitive science favours the alternatives of complexity and probability as principles of mental processes organization. The field of the event creation has a spatial-temporal constraint that must be taken into account by the logic of social cognition.

Society is a system with reflection, which is quite obvious. It is not quite clear that the consequence of this property is a choice of a part of one's own history to justify present and future. The subjects of a social action should solve the problem every time and again, the problem being what information from the past to be included in the process of generating the future. That does not exclude a repetition of positive and negative experiences. The depth of descending down the chains of the cause-effect relations as well as the space of social impacts transference are limited by bifurcation points, which are the points of choice from the opportunities available or points of creating new ways of development in the public system. Localization of these points in space and time reflects the measure of social events individualization.

Therefore, explanation of social facts by serious historic reasons is far from being always true. For example, it is hardly correct to explain an authoritarianism trend, existing in contemporary political life, by the peculiarities of national history.

It is worth while dwelling on the difference between psychological and sociological ways of description and explanation. The former appeals either to common properties of mental response or to a subject's individual characteristics. The latter appeals to psychic realities, thus, considering them as a reaction to cultural and historic impacts. For example, a sociological explanation as applied to the authoritarianism phenomenon implies that "love of a strong power" is an actual property that is present in the mentality and passed on from generation to generation. With reference to a particular individual it is a part of social environment. If authoritarianism did not exist in the form of beliefs and prejudices, it would not be passed on to the next generation or other generations as long as the social memory lasts.

The following explanation is always possible within the sociological model: an authoritarian (anti-democratic) trend occurs as a psychological reaction to a complex social environment, and it is stored in generations since these determinants are preserved. Both cases imply translation of either objective (social) environmental factors or mental ones. 
Explanation of the authoritarian features of human nature is another matter. It implies that the causes of this complex are not in the past but in the present; they are not in the external social reality but in a specific way of responding to a wide range of external stimuli. This means that the features of authoritarian consciousness appear in this social situation again, people (more specifically, only some people, their minor part) produce them by themselves. Others (who are always more numerous) adopt this mentality to the extent that the authoritarianism ideas suit their interests. Therefore, the psychological analysis involves the study of individual predisposition to an authoritarian tendency (Adorno, 2001). The conformism phenomenon is universal but it does not explain social changes, and, hence, it does not exhaust the nature of social determinism. It is partly due to conformism that the authoritarianism complex can exist in the society at a safe minimum if there are no favorable conditions for it and the channels of its distribution overlap.

So, psychological explanation involves reference to the general laws of functioning of human psyche and individuality. This, however, is the same, if we assume that "to be individual" is an inherent quality of human nature. Individual originality and contradictory nature of the subjects of social action are important variables in the analysis of social conditions and development trends. These factors are beyond all calculation, which is a different matter.

It should be emphasized once again that the peculiarity of the social system is that its elements - individuals - have autonomy of properties and relations. The presence of systemic qualities is characteristic of simple objects. Simple systems are such systems due to the fact that they can be described one way, with the language of the properties of the same level, whereas many of the essential features of society can be expressed in terms of human nature or specificity of human psychology.

\section{Conclusions}

The above analysis results in the following generalizations:

- the state of the methodological discourse questions the possibility of creating an algorithm of translation from the language of sociological theories into the language of psychological knowledge to implement the nomological synthesis;

- the I-S opposition retains the antinomic signs at the level of philosophical generalizations;

- explanation of social realities by the past condition of the society is limited to the points of choice and / or creativity;

- psychological explanation is adequate in relation to the events in loci which are sensitive to individual characteristics of the subjects of social action.

\section{References}

Adorno, T. (2001). Issledovanie avtoritarnoi lichnosti [The Research of Authoritarian Personality Study]. Ed. by V.P. Kultygina, doctor of philosophical sciences. Moscow, Serebrianye niti, $416 \mathrm{p}$.

Bazhenov, L.B. (2006). Veroiatnostnaia prichinnost' i teoriia propenzitivnosti K. Poppera [Probabilistic Causality and K. Popper's Propensity Theory]. Spontannost' i determinism [Spontaneity and Determinism]. Moscow, Nauka, 323 p.

Jorgensen, M., Phillips, L. (2002). Discourse Analysis as Theory and Method. London, Thousand Oaks, New Delhi, SAGE Publications Ltd., 229 p.

$$
-576-
$$


Kravchenko, A.V. (2013). Ot iazykovogo mifa $k$ biologicheskoi real'nosti: pereosmysliaia poznavatel'nye ustanovki iazykoznaniia [From the Language Myth to Biological Reality: Rethinking the Epistemological Assumptions of Linguistics]. Moscow, Rukopisnye drevnie pamiatniki Drevnei Rusi, 388 p.

Kravchenko, S.A. (2011). Sotsiologiia v dvizhenii k vzaimodeistviiu teoretiko-metodologicheskikh podkhodov [Sociology in Motion Towards Interaction of Theoretical and Methodological Approaches], In Sotsis [Sociological Studies], 1. Available at: http://www.isras.ru/files/File/Socis/2011-1/Kravchenko. pdf (accessed April 10, 2012).

Leontovich, O.A. (2011). Metody kommunikativnykh issledovanii [Methods of Communicative Studies]. Moscow, Gnosis, 224 p.

Moiseev, N.N. (1990). Chelovek $i$ noosphera [The Man and the Noosphere]. Moscow, Mol. gvardiia, $351 \mathrm{p}$.

Neskriabina, O.F. (2001). Individual'nost': na granitse real'nogo i ideal'nogo [Individuality: on the Border of the Real and the Ideal]. Krasnoyarsk, SibIuI MVD Rossii, $160 \mathrm{p}$.

Popper, K. (2004). Predpolozheniia i oproverzheniia: Rost nauchnogo znaniia [Conjectures and Refutations: The Growth of Scientific Knowledge]. Moscow, Izd-vo AST, 638 p.

Rozov, N.S. (2002). Filosofiia i teoriia istorii v 2-kh kn. Kn. 1. Prolegomeny [Philosophy and Theory of History in 2 vol. Vol. 1. Prolegomena]. Moscow, Logos, 655 p.

Sachkov, Iu.V. (2006). Evoliutsiia ucheniia o prichinnosti [Evolution of the Doctrine of Casuality]. Spontannost' i determinizm [Spontaneity and Determinism]. Moscow, Nauka, 16-42.

Ticher, S. (2009). Metody analiza teksta i diskursa [Methods of Text and Discourse Analysis]. Khar'kov, Izd-vo Gumanitarnyi tsentr, 356 p.

Zdravomyslov, A.G. K voprosu o kul'ture sotsiologicheskogo myshleniia [On Culture of Sociological Thinking]. Available at: http://www.isras.ru/files/File/publ/K_voprosu_o_kult_ Zdravomyslov.pdf (accessed April 12, 2012).

\section{Индивидуальное и социальное:}

пределы номологического синтеза

\section{и возможности социальной аналитики}

\section{О.Ф. Нескрябина}

Сибирский федеральный университет Россия, 660041, Красноярск, пр. Свободный, 79

\footnotetext{
В статье рассматриваются некоторые проблемные отнотения между индивидуальным и социальным уровнями бытия и познания общества. Отмечается многообразие и недостаточность интеграчии методологических подходов к анализу системной организации общества. Ставится вопрос об онтологическом статусе категории «уровень». Автор приходит к выводу о том, что «уровень» принадлежит двум языкам описания объекта: предметному и метаязыку, что не всегда учитывается при создании обобщзающих конщептов, отражающих спещиирику социального детерминизма, специифику отношения «часть-иелое» в системе, включающей сознание, челеполагание, творчество.
} 
Автор приходит к выводу, что методологический плюрализм является отражением антиномичности парь «индивидуальное-социальное» («И-С»), что номологический синтез ограничен данной антиномичностью и анализ этих границ (пределов) имеет эвристический смысл. Он состоит в уточнении содержания психологического анализа для понимания сочиальных реалий. Психологическое объяснение работает в отношении событий, происходящих в локусах, чувствительных к индивидуальным особенностям субъектов сочиального действия.

Социальный детерминизм характерен: разной глубиной взаимопроникновения индивидуального и социильного; наличием и динамических, и вероятностных закономерностей, разной степенью подобия элементов и системы, индивидуального и социиального.

Следствием данных особенностей является то, что не всегда правильно объяснять соичильнье реалии глубокими историческими причинами, поскольку индивидуальность в социуме проявляется, в частности, в том, какое историческое время будет включено в актуальное соииальное бытие. Объяснение общественных реалий прошлым состоянием социума ограничено точками выбора и/ или творчества.

Ключевые слова: система, уровень, синтез, методология, сочиальная аналитика, социальный детерминизм, индивидуальность.

Научная специильность: 09.00.00-философские науки. 